\title{
E-learning Platforms Used by the EFL Teacher during Distance Learning
}

\author{
Gede Didit Ogi Wirasatya ${ }^{1 *}$, Luh Putu Artini ${ }^{\mathbf{2}}$ Luh Gede Eka Wahyuni
${ }_{1,2,3}$ English Language Education, Ganesha University of Education, Singaraja, Indonesia
}

\section{A R T I C L E I N F O}

Article history:

Received September 10, 2021

Revised September 12, 2021

Accepted November 20, 2021

Available online December 25, 2021

Kata Kunci:

Platform E-Learning, Pembelajaran

Jarak Jauh

Keywords:

E-Learning Platforms, Distance

Learning

DOI:

http://dx.doi.org/10.23887/jpbi.v9i3.42 $\underline{996}$

\section{A B S T R A C T}

Due to the Covid-19 outbreak, learning activities had to be changed from face-to-face activities in class to distance learning. The e-learning platform has been essential to use since the covid-19 outbreak. However, online learning has several obstacles, such as the lack of facilities owned by students. Some parents and students face a problem during distance learning because they do not have a computer or android device. This study aims to analyze the bold learning platform used by EFL teachers during the covid-19 outbreak and analyze the use during distance learning. This research uses a descriptive qualitative approach. Observations and interviews were used as methods in this study. The subject of this research is an EFL teacher. This study indicates that EFL teachers entirely use WhatsApp as an e-learning platform to carry out teaching activities during distance learning using several steps. First, the teacher sends a greeting, reviewing the previous material and information on today's material. Second, the teacher provides additional material in e-modules and learning videos. Third, the teacher gives some assignments to students. Fourth, the teacher collects the collection of assignments. This research can be used as a reflection on how the implementation of classroom language used by the EFL teacher during distance learning.

This is an open-access article under the CC BY-SA license. Copyright (C) 2021 by Author. Published by Universitas Pendidikan Ganesha.

\begin{abstract}
A B S T R A $\boldsymbol{K}$
Akibat wabah Covid-19, kegiatan belajar harus diubah dari kegiatan tatap muka di digunakan sejak wabah covid-19. Namun pembelajaran online memiliki beberapa kendala, seperti kurangnya fasilitas yang dimiliki oleh siswa. Beberapa orang tua dan siswa menghadapi masalah selama pembelajaran jarak jauh karena mereka tidak menganalisis platform atau perangkat android. Penelitian ini bertujuan untuk wabah covid-19 dan menganalisis penggunaannya selama pembelajaran jarak jauh. Penelitian ini menggunakan pendekatan kualitatif deskriptif. Observasi dan wawancara digunakan sebagai metode dalam penelitian ini. Subjek penelitian ini menggunakan WhatsApp sebagai platform e-learning untuk melakukan kegiatan mengajar selama pembelajaran jarak jauh menggunakan beberapa langkah. Pertama, guru menyampaikan salam, mengulas materi sebelumnya dan informasi materi hari Kedua, guru memberikan materi tambahan berupa e-modul dan video mengumpulkan kumpulan tugas. Penelitian ini dapat digunakan sebagai refleksi tentang bagaimana implementasi bahasa kelas yang digunakan oleh guru EFL selama pembelajaran jarak jauh.
\end{abstract}

\section{INTRODUCTION}

Due to the covid-19 outbreak, learning activities are forcedly changed from face-to-face in-class activities into distance learning. The implementation of online learning is officially advised by the Minister of Education and Culture of the Republic of Indonesia who announced that all education units must be changed into online learning (Ambarita, 2021; Anggrasari, 2020; Raharja et al., 2019). Implementing distance learning surely requires some e-learning platforms in conducting distance learning (Abumalloh et al., 2021; Almaiah et al., 2020; Aprilia et al., 2020; Sindiani et al., 2020). E-learning platforms is really important to utilize since the covid-19 outbreak. E-learning platforms are significant since they are used in managing the learning process, doing an evaluation, informing the students, and communication services (Ja'ashan, 2020; Lapitan et al., 2021; Yawson \& Yamoah, 2020). In addition, it is also really helpful for both the teachers and the students in conducting teaching and learning activity. E-learning platforms' utilization in the learning process can improve efficiency and effectiveness therefore the students' highest potency can be achieved (Ardini et al., 2020; Arifuddin et al., 2020; Rahmat, 2020; Ristanto et al., 2020).

Based on the results of observations and interviews with one of the English teachers in SMP N 6 Kintamani, the teacher explained that at the first online meeting, she has ever tried to use Google Meeting and 
Zoom but the participants were only ten of two classes in grade 7. As the result, the teacher did not use video conferences such as Zoom, Google meeting, Cisco WebEx in remote learning due to the student's problems. Furthermore, the teacher mentioned that the facilities used by the students are limited, for instance, mobile phones and laptops, therefore, most of them borrow them from their parents. The findings of previous studies also stated that the problem faced by some parents and students during the implementation of remote learning is that they do not have a computer or an Android device (Efriana, 2021; Mufaziah \& Fauziah, 2020; Rigianti, 2020; Wardani et al., 2020). Most of their parents athe also cannot help their children to apply to those video conferences. The data package had by the students is also limited. Conducting remote learning, particularly using video conferences are surely requires a high cost that makes both students and their parents from middle-lower class economies do not have enough budget to provide the data package ((Efriana, 2021; Hutauruk \& Sidabutar, 2020; Primasari \& Zulela, 2021). Moreover, the internet signal was not good enough because they live in the villages. It is also supported previous research that even though most the students have the internet in their hands, they still face difficulty in accessing the internet network due to geographical location that affects the unstable network (Efriana, 2021; Hutauruk \& Sidabutar, 2020; Windhiyana, 2020). Some students have already mobile phones however the problem is it did not support conducting video conferences.

E-learning platforms used in distance learning can be in the form of applications and online platforms. First, there are some applications used by the teacher and students starting from junior high school to college students during the covid-19 pandemic. The applications are Zoom, Google Meeting, Skype, and so forth as video conferences (Marsiding, 2021; Mpungose, 2021; Putra, 2021; Suhery et al., 2020). There are some applications used during online learning in the form of video conferences namely zoom, google meeting, and WebEx (Abidah et al., 2020; Putra, 2021; Setyawan et al., 2020). Previous research also stated that nowadays, many e-learning platforms are applied by the teachers due to the covid-19 pandemic namely Rumah Belajar, Quipper School, Ruang Guru, Google Classroom, and so on (Haka et al., 2020; Kumar et al., 2020; Octaberlina \& Muslimin, 2020). Second, some online platforms are used namely Google Classroom, Schoology, Edmodo, or even WhatsApp that both teachers and students use as learning platforms (Hasyim \& Eldiana, 2020; Resty et al., 2019; Sefriani et al., 2021). Several online learning platforms are available for the English teachers such as e-mail, google form, Schoology, posting teacher notes, and social e-learning platforms that are used in distance learning (Solehana et al., 2019; Widyaningrum et al., 2020; Zhang et al., 2020). Distance learning is defined as a learning activity in which conducted in an online way by implementing e-learning platforms such as Google Classroom, Schoology, Edmodo, WhatsApp, and so on. Distance learning is a learning process that implements technology that both the students and teacher uses in distance teaching and learning activities forth (Churiyah et al., 2020; Lase et al., 2021; Mamahit, 2020). Distance learning is known as a learning process by utilizing technological advances such as multimedia technology, video, virtual classes, animated online text, voice messages, e-mail, telephone conferencing, and online video streaming, in which both students and teachers do not meet face to face in one place (Assidiqi \& Sumarni, 2020; Goudeau et al., 2021; Kalyuga, 2012).

In the Indonesian research context, previous research has conducted the latest research on e-learning platforms used during the COVID-19 outbreak (Tathahira \& Sriayu, 2020; Wardany et al., 2021). However, the context of their studies was in vocational school and senior high school, and have yet to focus on e-learning platforms used in junior high school, particularly in SMP N 6 Kintamani. Other research conducted research on the utilization of learning platforms in the Madrasah Ibtidaiyah Teacher Education (PGMI) Study during the covid19 period only briefly discussed the e-learning platforms used in conducting distance learning Saputra et al. (2021). Therefore, the purpose of this study was to analyze the e-learning used by EFL teachers during the covid-19 outbreak at SMP N 6 Kintamani; and analyze the use of e-learning platforms during distance learning. This study is urgent to conduct since it is covid-19, which makes many various e-learning platforms were used during the online teaching and learning process. Therefore, knowing the e-learning platform used by the teacher can give a beneficial contribution for the present or future teachers to use for appropriate e-learning platform in distance learning. Moreover, this study can be used as guidance in implementing for e-learning platforms to prepare preservice teachers when conducting distance learning.

\section{METHOD}

This study used a descriptive qualitative method. By using qualitative research, the researcher analyzed a social phenomenon namely e-learning platforms used by the teacher in junior high school by investigating a person, in this case, who is an EFL teacher who teaches English subjects during remote teaching. The data were collected by observation and interview. The observation was conducted to find out the data about what e-learning platforms are used and the use of it during distance learning by the teacher in SMP N 6 Kintamani. Furthermore, the interview was also conducted using a voice note by WhatsApp application to support the data of observation since the teacher was not able to conduct the interview directly face to face or using any video conferences. The 
interview was informal. The researcher only asked open-ended questions and allowed the participant to answer the questions based on what they knew about it.

The participant of this study was an EFL teacher at SMP N 6 Kintamani as the main source of data. The researcher chose only one teacher because of 9 English teachers in SMP N 6 Kintamani, only one teacher gave her consent in this research and after doing preliminary observation and interview, only a teacher who could conduct the distance learning well enough using WhatsApp as the medium used in distance learning. The researcher used two steps to collect the data. The first step was observation to see what e-learning platforms were used and their use of them during a covid-19 outbreak. The observation was conducted by joining a group of class $7 \mathrm{H}$ and I (it was labeled from A to I). The second step was a semi-structured interview using a voice note of the WhatsApp application to support the data of the observation. Those methods were used to obtain the data from the participant based on their understanding and experiences. The analysis of all data was organized to obtain findings that were interpreted appropriately. There were three steps in analyzing the data starting with transcribing the data. The next step was reducing the data. The last step that had to be done was describing the data.

\section{RESULT AND DISCUSSION}

\section{Result}

This section provides the result of observation and interview. The researcher observed the e-learning platforms through observing 10 meetings. The observation was conducted by joining a group consisting of grade $7 \mathrm{H} \& \mathrm{I}$ (the classes were labeled from A to I). In addition, the interview was also conducted to support the data of the observation. The use of e-learning platforms (WhatsApp) during distance learning was presented in Table 1.

Table 1. E-learning platforms used by the EFL teacher during distance learning

\begin{tabular}{l}
\hline \multicolumn{2}{c}{ TOPIC } \\
\hline Telling date, and months \\
(CHAPTER 3) \\
Giving exercise for the \\
previous materials: telling \\
time, days, dates, and \\
months \\
(CHAPTER 3)
\end{tabular}

Giving daily test of the materials: telling time, days, date, and month (CHAPTER 3) Stating things (CHAPTER 4)

1. The use of articles "a" and "an"

2. The use of "have" and "has"

(CHAPTER 4)

Stating public place

(CHAPTER 4)

\section{DESCRIPTION}

The teacher conducted distance learning using WhatsApp in the first meeting to continue learning material from the previous meeting in chapter 3. Previously, the teacher taught about telling time and days. At the end of the class, the tasks were given and must be submitted no later than 2 p.m.

The teacher preferred to use WhatsApp in meeting 2 to give learning exercises for the students since all materials in chapter 3 have been done. There are 4 exercises namely:

$$
\begin{array}{ll}
\text { 1. The ways how to ask the time } \\
\text { 2. The ways how to ask days } \\
\text { 3. The ways how to ask the date } \\
\text { 4. The ways how to ask the month }
\end{array}
$$

They are required to submit it no later than noon.

The teacher used WhatsApp to conduct a daily test consisting of 40 multiple choice questions and 10 questions of the essay. The daily test was conducted by sending the questions in the form of pictures because most of the students were confused about how to use google form.

The teacher used WhatsApp to conduct the learning process. The students were instructed to read their book first on pages 59-64 and they could ask anything if they did not understand the material. At the end of the lesson, students were given 4 tasks to find:

1. The name of 10 things in the bedroom.

2. The name of 10 things in the living room.

3. The name of 10 things in the bathroom

4. The name of 10 things in the kitchen.

Students must read and record it in the form of voice recording and then submitted it to the teacher personally.

The teacher applied for WhatsApp to conduct teaching and learning activities. The material was sent in the form of an e-module and four explanation videos made directly by the teacher. At the end of the meeting, tasks were given to the students.

The teacher use WhatsApp to conduct teaching activities by sending some pictures related to the material, text messages, and four explanation videos. Students were also given three tasks: 1) writing the name of rooms in the 


\begin{tabular}{|c|c|}
\hline TOPIC & DESCRIPTION \\
\hline $\begin{array}{l}\text { Measuring uncountable } \\
\text { nouns } \\
\text { (CHAPTER 4) }\end{array}$ & $\begin{array}{l}\text { students' house, 2) making sentences based on the pictures given, 3) filling up } \\
\text { the missing sentence with the correct preposition. } \\
\text { The teacher uses WhatsApp to conduct teaching activities. the materials were } \\
\text { sent by giving an e-module in the form of some pictures, one learning video } \\
\text { derived from YouTube, and four explanation videos directly made by the } \\
\text { teacher. In the end, students were given three tasks in the form of making } 5 \\
\text { sentences based on the situation in the picture. }\end{array}$ \\
\hline $\begin{array}{l}\text { 1. Many and much } \\
\text { (countable and } \\
\text { uncountable nouns) }\end{array}$ & $\begin{array}{l}\text { The teacher use WhatsApp to conduct teaching activities still about chapter } 4 \\
\text { which covers: Those were sent through e module in the form of some pictures } \\
\text { and a video from YouTube. At the end of the lesson, the teacher gave tasks } \\
\text { about: }\end{array}$ \\
\hline (CHAPTER 4) & $\begin{array}{l}\text { 1. Making conversation about the number of things based on the pictures } \\
\text { given } \\
\text { 2. Making sentences by mentioning the name, number, and location of } \\
\text { things (have and has). }\end{array}$ \\
\hline $\begin{array}{l}\text { Giving exercises related to } \\
\text { the previous material } \\
\text { (preposition, many, much, } \\
\text { there is, there are) } \\
\text { (CHAPTER 4) }\end{array}$ & $\begin{array}{l}\text { The teacher applied the WhatsApp application for giving some practices or } \\
\text { exercises related to the material in the previous meeting. The exercises are: } \\
\text { 1. Making sentences based on the picture given } \\
\text { 2. Making voice recordings based on the sentences made. }\end{array}$ \\
\hline $\begin{array}{l}\text { Animals } \\
\text { (CHAPTER 4) }\end{array}$ & $\begin{array}{l}\text { The teacher applied WhatsApp for giving the students tasks related to chapter } 4 \\
\text { about animals. The tasks are: } \\
\text { 1. Reading the name of the animals based on the picture and record your } \\
\text { voice! } \\
\text { 2. Making some sentences by mentioning the name of animals and the } \\
\text { amount of it. }\end{array}$ \\
\hline
\end{tabular}

The e-learning platform used during distance learning was WhatsApp only from observation 1 to 10 . From those, each meeting covered different topics starting from meeting 1 to 10 (Table 1). Chapter 3 covered observations 1 to 3 meanwhile chapter 4 covered observations 4 to 10. More detail about the reason for using full WhatsApp was presented in the following interview quotation.

"The limitation of students' learning facilities such as poor internet connection in some place/area. In addition, the data package provided by the government is still not maximally utilized by the students. Therefore, it causes a lack of students' data packages that also affect the use of WhatsApp as the alternative for conducting distance learning. Apart from data package, lack of knowledge in using any learning application also makes me mostly use WhatsApp during distance learning." (Int01-15-12-2021)

As mentioned previously, WhatsApp was fully used by the EFL teacher during distance learning. This kind of e-learning platform was used through some learning steps or processes as follows: greeting the students, reviewing the previous material, informing today's topic, giving additional material, giving tasks, informing the tasks due date, and farewell. The teacher greeted the students during the distance learning specifically at the beginning of the learning process. More details about the expressions, namely "Good morning students, I hope all of you have great condition". The teacher-reviewed shortly the previous material before the learning process began. More detail about the expression of previous material namely "Last week, we have already learnt about telling time and days". The teacher gave brief information related to the topic of today's meeting before the learning process began. More detail about the expression of informing today's topic is "Now, we will continue the material to learn about telling the month and date".

The teacher gave additional learning material in the form of e module and e-learning videos. E-learning videos were manually made by the teacher. More detail about the reason for giving e-learning videos by herself namely; "I give some learning videos to make the students easier to understand the material. The manual videos were made to be a simple version of YouTube Video. Sometimes the learning videos on YouTube are too long which make the students bored and do not listen to it as a whole. Therefore, I must make or retake learning videos for discussing the main topic". The teacher informed the students before the additional materials were shared with them. The expressions of giving additional material are "I will give you additional material...", "Please write the additional material".

The teacher gave tasks in the form of making a voice recording, reading comprehension, and making sentences. More detail about the reason for giving e-learning videos by herself are "After watching the video above, make voice recording about reading the names of months in English". "Answer those questions". "Please read the example in the table on page 51, after that write down the birthday of your big family member". There 
are some reasons why the teacher gave those tasks for the students such as the teacher wanted to know how far the students had understood about the learning material during distance learning. More detail about the reason for giving tasks are "Assignments are given to check students' understanding and ensure that the material presented can be understood well. Others than that it also to determine what steps I can do if the material is not well understood by the students. In addition, I must know how far students' understanding of the material that has been learned". The teacher informed the tasks' due date through sending the message in WhatsApp group. More detail about the due date of the tasks are "I hope all of you can do this task. Please collect the result of your work no later than 2 PM in the afternoon to my personal WA". For the tasks' submission, the students had to submit theirs to the teacher personally. More detail about the way students submitted their tasks are "I ask the students to take some pictures of their tasks, then they have to send it to me in WhatsApp personally". The teacher conveyed a massage indicating farewell at the end of the lesson in WhatsApp group. More detail about farewell is "Have a great day", "Good luck".

\section{Discussion}

Based on the result of this study, the result revealed that after observing meetings 1 to 10, the EFL teacher in SMP N 6 Kintamani used 100\% WhatsApp only as an e-learning platform during distance learning. In discussing learning material, the students prefer to use the WhatsApp application with 535 respondents (64.61\%) specifically in the WhatsApp group rather than other e-learning platforms (Padmo et al., 2020). The teacher mentioned that the use of the WhatsApp application only as an e-learning platform was because of the limitations of students' learning facilities such as lack of data package and poor internet connection in some places since most of the students live in the village. The teacher also stated that a lack of knowledge in using any learning application makes the teacher mostly used WhatsApp during distance learning. Students have limited facilitates for conducting online learning like computers, laptops, or smartphones, and insufficient internet access and quotas (Hutauruk \& Sidabutar, 2020; Shodiq \& Zainiyati, 2020; Windhiyana, 2020). Many students also complained that mostly all of them only have data packages for WhatsApp only. In addition, most of the students in grade $7 \mathrm{H}$ and I still did not know how to operate for other e-learning platforms such as Zoom, Google Meet, Google Classroom, and so forth. It was because they were still in grade 7 and were known about e-learning platforms for the first time. However, mostly all of them have already used WhatsApp to send some messages out of the learning processes. Therefore, the teacher conducted distance learning through WhatsApp as the alternative for the students (Azhari \& Fajri, 2021; Churiyah et al., 2020; Goudeau et al., 2021; Mamahit, 2020; Mansur et al., 2021).

WhatsApp as the e-learning platform was used through sending messages consisting of greeting, reviewing the material in the previous meeting, telling today's material, giving learning videos made by the teacher and taken from other sources such as YouTube, providing e-module shared in form of some pictures, and checking the students' understanding by giving tasks to the students (Abroto et al., 2021; Mulyono et al., 2021; Singh et al., 2020). After comparing this research and other research conducted a research on the changes from offline to online learning during covid-19 outbreaks, the result of the study revealed that distance learning was conducted through Google Classroom and WhatsApp (Faizah et al., 2021; Haka et al., 2020; Rosmiati \& Lestari, 2021). There were some steps of conducting distance learning namely the material was sent by the lecturer to the class leader or WAG, students accessed the material, the lecturer gave assignments for the students, and deciding the deadline for collecting the assignments (Faizah et al., 2021; Kumar et al., 2020). When the teacher only gave tasks for the students during distance learning, it can make the students feel under pressure and it causes learning anxiety. The teaching and learning system during the COVID-19 outbreak has caused a variety of panic and had many impacts one of them is some students complain that online lectures caused anxiety and were not focused while learning the material delivered (Hutauruk \& Sidabutar, 2020; Shodiq \& Zainiyati, 2020).

WhatsApp is considered to be a good application as an alternative for conducting teaching and learning activities. The implementation of WhatsApp as an e-learning medium to deliver classroom languages is helpful particularly for the teacher when conducting distance learning (Daheri et al., 2020; Singh et al., 2020; Susilowati, 2020). Previous research found that WhatsApp media is very useful in distance learning (PJJ) or online learning and the cost of using this application is very cheap if compared with other applications (Kusuma \& Hamidah, 2020; Suriyani Djamdjuri \& Kamilah, 2020). This application is also great and appropriate for the students who have a lack of data package and poor connection since it does not require so much signal to use this e-learning platform. It was so cheap application and did not consume more signals and quotes in practice therefore the students no longer worried about the cost when using this application (Kholis et al., 2020; Mulyono et al., 2021; Sahidillah \& Miftahurrisqi, 2019). Since it does not consume so much signal, the teacher can easily share the classroom languages without any obstacles. Via WhatsApp, the teacher can send classroom languages or learning material fast as well as students do (Kholis et al., 2020; Rosmiati \& Lestari, 2021). Furthermore, through this application students must not only learn the material at a schedule determined by the teacher but they can access the material whenever and wherever they want. Besides, most of the students in SMP N 6 Kintamani used this application that indicates this application is really easy to utilize. Most students (74\%) liked to share new 
information on WhatsApp and this app can also increase the students to be brave and confident to communicate asynchronously with the teacher in remote learning. Therefore, through this application learning anxiety of the students can be reduced (Kheryadi, 2017).

\section{CONCLUSION}

WhatsApp was fully used by the EFL teacher to conduct distance learning through some teaching steps namely sending messages consisting of greeting, reviewing the material in the previous meeting, telling today's material, giving learning videos made by the teacher, and taking from other sources such as YouTube, providing e-module shared in form of some pictures, checking the students' understanding by giving tasks to the students, and informing the way submitting the tasks. This research can be used as a reflection on how the implementation of classroom language used by the EFL teacher during distance learning. In addition, the researcher also has suggestions for other researchers to conduct further research about the implementation of WhatsApp in reducing learning anxiety.

\section{REFERENCES}

Abidah, A., Hidaayatullaah, H. N., Simamora, R. M., Fehabutar, D., \& Mutakinati, L. (2020). The Impact of Covid-19 to Indonesian Education and Its Relation to the Philosophy of "Merdeka Belajar." Studies in Philosophy of Science and Education, 1(1), 38-49. https://doi.org/10.46627/sipose.v1i1.9.

Abroto, Anantama, \& Prastowo. (2021). Analisis Hambatan Proses Pembelajaran Daring dengan Menggunakan Aplikasi Whatsapp di Sekolah Dasar. Jurnal Basicedu, 5(3), 1632-1638. https://doi.org/10.31004/basicedu.v5i3.971.

Abumalloh, R. A., Asadi, S., Nilashi, M., Minaei-Bidgoli, B., Nayer, F. K., Samad, S., Mohd, S., \& Ibrahim, O. (2021). The impact of coronavirus pandemic (COVID-19) on education: The role of virtual and remote laboratories in education. Technology in Society, 67(September 2020), 101728. https://doi.org/10.1016/j.techsoc.2021.101728.

Almaiah, M. A., Al-Khasawneh, A., \& Althunibat, A. (2020). Exploring the critical challenges and factors influencing the E-learning system usage during the COVID-19 pandemic. Education and Information Technologies, 25(6), 5261-5280. https://doi.org/10.1007/s10639-020-10219-y.

Ambarita, E. (2021). Belajar Dari Rumah (Bdr) Menggunakan Padlet Alternatif E-Learning Pada Masa Pandemi Covid-19 (Studi Kasus Di Sman 56 Jakarta). JIRA: Jurnal Inovasi Dan Riset Akademik, 2(1), 30-36. https://doi.org/10.47387/jira.v2i1.70.

Anggrasari, L. A. (2020). Penerapan e-learning untuk meningkatkan kemampuan literasi digital di era new normal. Premiere Educandum: Jurnal Pendidikan Dasar Dan Pembelajaran, 10(2), 248. https://doi.org/10.25273/pe.v10i2.7493.

Aprilia, F., Lustyantie, N., \& Rafli, Z. (2020). The Effect of Reading Interest and Achievement Motivation on Students ' Discourse Analysis Competence. Journal of Education and E-Learning Research, 7(4), 368372. https://doi.org/10.20448/journal.509.2020.74.368.372.

Ardini, L., Iswara, U. S., \& Retnani, E. D. (2020). Efektivitas Penggunaan E-Learning Sebagai Media Pembelajaran Saat Pandemi Covid 19. JKBM:Jurnal Konsep Bisnis Dan Manajemen, 7(1), $72-81$. https://doi.org/10.31289/jkbm.v7i1.4333.

Arifuddin, Suwatra, \& Mahadewi. (2020). Pengembangan Konten E-learning Berorientasi Pendidikan Karakter Pada Mata Pelajaran Seni Budaya. Jurnal Edutech Undiksha, 8(2). https://doi.org/10.23887/jeu.v8i2.28942.

Assidiqi, M. H., \& Sumarni, W. (2020). Pemanfaatan Platform Digital di Masa Pandemi Covid-19. Prosiding Seminar Nasional Pascasarjana, 298-303.

Azhari, B., \& Fajri, I. (2021). Distance learning during the COVID-19 pandemic: School closure in Indonesia. International Journal of Mathematical Education in Science and Technology. https://doi.org/10.1080/0020739X.2021.1875072.

Churiyah, M., Sholikhan, S., Filianti, F., \& Sakdiyyah, D. A. (2020). Indonesia Education Readiness Conducting Distance Learning in Covid-19 Pandemic Situation. International Journal of Multicultural and Multireligious Understanding, 7(6), 491. https://doi.org/10.18415/ijmmu.v7i6.1833.

Daheri, M., Juliana, J., Deriwanto, D., \& Amda, A. D. (2020). Efektifitas WhatsApp sebagai Media Belajar Daring. Jurnal Basicedu, 4(4), 775-783. https://doi.org/10.31004/basicedu.v4i4.445.

Efriana, L. (2021). Problems of Online Learning during Covid-19 Pandemic in EFL Classroom and the Solution. Journal of English Language Teaching and Literature, 2(1).

Faizah, U., Ambarwati, R., \& Rahayu, D. A. (2021). From offline to online learning: Various efforts to secure the learning process during covid-19 outbreaks. Journal of Physics: Conference Series, 1747(1). 
https://doi.org/10.1088/1742-6596/1747/1/012002.

Goudeau, S., Sanrey, C., Stanczak, A., Manstead, A., \& Darnon, C. (2021). Why lockdown and distance learning during the COVID-19 pandemic are likely to increase the social class achievement gap. Nature Human Behaviour. https://doi.org/10.1038/s41562-021-01212-7.

Haka, N. B., Anggita, L., Anggoro, B. S., \& Hamid, A. (2020). Pengaruh Blended Learning Berbantukan Google Classroom Terhadap Keterampilan Berpikir Kreatif Dan Kemandirian Belajar Peserta Didik. Edu Sains Jurnal Pendidikan Sains \& Matematika. https://doi.org/10.23971/eds.v8i1.1806.

Hasyim, M., \& Eldiana, N. F. (2020). Eksperimentasi model PBL dan PjBL berbasis schoology terhadap pemecahan masalah matematika ditinjau dari self-efficacy. JP2M (Jurnal Pendidikan Dan Pembelajaran Matematika). https://doi.org/10.29100/jp2m.v6i2.1751.

Hutauruk, A., \& Sidabutar, R. (2020). Kendala pembelajaran daring selama masa pandemi di kalangan mahasiswa pendidikan matematika: Kajian kualiatatif deskriptif. Journal of Mathematics Education and Applied, 02(01), 45-51. https://doi.org/10.36655/sepren.v2i1.364.

Ja'ashan, M. (2020). The Challenges and Prospects of Using E-learning among EFL Students in Bisha University. Arab World English Journal, 11(1), 124-137. https://doi.org/10.24093/awej/vol11no1.11.

Kalyuga, S. (2012). Interactive distance education: A cognitive load perspective. Journal of Computing in Higher Education. https://doi.org/10.1007/s12528-012-9060-4.

Kholis, A., Nahdlatul, U., \& Yogyakarta, U. (2020). LET Linguistics, Literature, and English Teaching Journal THE USE OF WHATSAPP APP IN DISTANCE LANGUAGE LEARNING. 10(2), 24-43.

Kumar, J. A., Bervell, B., \& Osman, S. (2020). Google Classroom : insights from Malaysian higher education students ' and instructors ' experiences. Education and Information Technologies, 25. https://doi.org/10.1007/s10639-020-10163-x.

Kusuma, J. W., \& Hamidah. (2020). Perbandingan Hasil Belajar Matematika Dengan Penggunaan Platform Whatsapp Group Dan Webinar Zoom Dalam Pembelajaran Jarak Jauh Pada Masa Pandemik Covid 19. Jurnal Ilmiah Pendidikan Matematika, 5(1), 97-106. https://doi.org/10.26877/jipmat.v5i1.5942.

Lapitan, L. D., Tiangco, C. E., Sumalinog, D. A. G., Sabarillo, N. S., \& Diaz, J. M. (2021). An effective blended online teaching and learning strategy during the COVID-19 pandemic. Education for Chemical Engineers, 35(May 2020), 116-131. https://doi.org/10.1016/j.ece.2021.01.012.

Lase, D., Zega, T. G. C., \& Daeli, D. O. (2021). Parents' Perceptions of Distance Learning during COVID-19 Pandemic in Rural Indonesia. SSRN Electronic Journal, 13(2), 101-111. https://doi.org/10.2139/ssrn.3890610.

Mamahit, C. E. J. (2020). Blended Model of Distance Learning : Does It Effective ? Jurnal Pendidikan Teknologi Kejuruan, 3(4), 176-186. https://doi.org/10.24036/jptk.v3i4.15223.

Mansur, H., Jumadi, Mastur, Utama, A. H., \& Prastitasari, H. (2021). The Problem of Distance Learning During the Covid-19 Pandemic. Ilkogretim Online - Elementary Education Online, 20(4), 168-175. https://doi.org/10.17051/ilkonline.2021.04.19.

Marsiding, Z. (2021). Efektifitas Penggunaan Media Zoom Terhadap Pembelajaran Pada Masa Pandemi Covid19. Jurnal Ilmiah Pranata Edu, 2(1), 33-39. https://doi.org/10.36090/jipe.v2i1.931.

Mpungose, C. B. (2021). Lecturers' reflections on use of Zoom video conferencing technology for e-learning at a South African university in the context of coronavirus. African Identities. https://doi.org/10.1080/14725843.2021.1902268.

Mufaziah, E., \& Fauziah, P. (2020). Kendala Orang Tua dalam Mendidik Anak Usia Dini pada Saat Pandemi Covid 19. Jurnal Obsesi, 5(2). https://doi.org/10.31004/obsesi.v5i2.746.

Mulyono, H., Suryoputro, G., \& Jamil, S. R. (2021). The application of WhatsApp to support online learning during the COVID-19 pandemic in Indonesia. Heliyon, 7(8), e07853. https://doi.org/10.1016/j.heliyon.2021.e07853.

Octaberlina, L. R., \& Muslimin, A. I. (2020). EFL Students Perspective towards Online Learning Barriers and Alternatives Using Moodle / Google Classroom during COVID-19 Pandemic. International Journal of Higher Education, 9(6), 1-9. https://doi.org/10.5430/ijhe.v9n6p1.

Padmo, D., Terbuka, U., Ardiasih, L. S., \& Terbuka, U. (2020). The Impact Of COVID19 On The International Education System. The Impact Of COVID19 On The International Education System, February 2021. https://doi.org/10.51432/978-1-8381524-0-6.

Primasari, I. F. N. D., \& Zulela. (2021). Kendala Pembelajaran Jarak Jauh (PJJ) Secara Online Selama Masa Pandemik Covid-19 di Sekolah Dasar. JIKAP PGSD: Jurnal Ilmiah Ilmu Kependidikan, 5(1), 64-73.

Putra, R. W. P. (2021). Improving the Students' Motivation in Learning English through Google Meet during the Online Learning. English Learning Innovation, 2(1), 35-42. https://doi.org/10.22219/englie.v2i1.14605.

Raharja, U., Lutfiani, N., Handayani, I., \& Suryaman, F. M. (2019). Motivasi Belajar Mahasiswa Terhadap Metode Pembelajaran Online iLearning+ Pada Perguruan Tinggi. Sisfotenika, 9(2), 192. https://doi.org/10.30700/jst.v9i2.497. 
Rahmat, I. (2020). Implementasi Andragogi Platform E-learning pada Blended Learning di Universitas Negeri Padang. Journal of Education Technology, 4(2), 133. https://doi.org/10.23887/jet.v4i2.24817.

Resty, Z. N., Muhardjito, M., \& Mufti, N. (2019). Discovery Learning Berbantuan Schoology: Upaya Peningkatan Kemampuan Berpikir Kritis. Jurnal Pendidikan: Teori, Penelitian, Dan Pengembangan. https://doi.org/10.17977/jptpp.v4i2.12040.

Rigianti, H. A. (2020). Kendala Pembelajaran Daring Guru Sekolah Dasar Di Banjarnegara. Elementary School: Jurnal Pendidikan Dan Pembelajaran Ke-SD-An, 7(2). https://doi.org/10.31316/esjurnal.v7i2.768.

Ristanto, R. H., Rusdi, R., Mahardika, R. D., Darmawan, E., \& Ismirawati, N. (2020). Digital Flipbook Imunopedia (DFI): A Development in Immune System e-Learning Media. International Journal of Interactive Mobile Technologies (IJIM), 14(19), 140-162. https://doi.org/10.3991/ijim.v14i19.16795.

Rosmiati, U., \& Lestari, P. (2021). Inovasi Model Pembelajaran PBI ( Problem Based Instruction ) Berbasis Whatsapp Sebagai Langkah Solutif Pembelajaran di Masa Pandemi Covid-19. JNPM (Jurnal Nasional Pendidikan Matematika), 5(1), 188-197. https://doi.org/10.33603/jnpm.v5i1.3708 Inovasi.

Sahidillah, M. W., \& Miftahurrisqi, P. (2019). Whatsapp sebagai Media Literasi Digital Siswa. Jurnal VARIDIKA, 1(1), 52-57. https://doi.org/10.23917/varidika.v1i1.8904.

Saputra, N., Hikmah, N., Yustitia, V., Saputra, M., Wahab, A., \& Junaedi, J. (2021). Implementation of Online Learning Using Online Media, During the Covid 19 Pandemic. Budapest International Research and Critics Institute (BIRCI-Journal): Humanities and Social Sciences, 4(2), 1802-1808. https://doi.org/10.33258/birci.v4i2.1857.

Sefriani, R., Sepriana, R., Wijaya, I., \& Radyuli, P. (2021). Blended Learning with Edmodo: The Effectiveness of Statistical Learning during the COVID-19 Pandemic. International Journal of Evaluation and Research in Education, 10(1), 293-299. https://doi.org/10.11591/ijere.v10i1.20826.

Setyawan, A., Aznam, N., \& Citrawati, T. (2020). Effects of the Google Meet Assisted Method of Learning on Building Student Knowledge and Learning Outcomes. Universal Journal of Educational Research, 8(9), 3924-3936. https://doi.org/10.13189/ujer.2020.080917.

Shodiq, I. J., \& Zainiyati, H. S. (2020). Pemanfaatan Media Pembelajaran E-Learning Menggunakan Whastsapp Sebagai Solusi Ditengah Penyebaran Covid-19 Di Mi Nurulhuda Jelu. Al-Insyiroh: Jurnal Studi Keislaman, 6(2), 144-159. https://doi.org/10.35309/alinsyiroh.v6i2.3946.

Sindiani, A. M., Obeidat, N., Alshdaifat, E., Elsalem, L., Alwani, M. M., Rawashdeh, H., Fares, A. S., Alalawne, T., \& Tawalbeh, L. I. (2020). Distance education during the COVID-19 outbreak: A cross-sectional study among medical students in North of Jordan. Annals of Medicine and Surgery, 59, 186-194. https://doi.org/10.1016/J.AMSU.2020.09.036.

Singh, C. K. S., Singh, T. S. M., Abdullah, N. Y., Moneyam, S., Ismail, M. R., Tek, E., Karupayah, T., Chenderan, K., Singh, M. K. R., \& Singh, J. K. S. (2020). Rethinking English language teaching through Telegram, Whatsapp, Google classroom, and Zoom. Systematic Reviews in Pharmacy, 11(11), 45-54. https://doi.org/10.31838/srp.2020.11.9.

Solehana, L., Asrori, A., \& Usman, A. (2019). The Development of E-Learning Teaching Material Based on Edmodo on Basic Competencies of National Integration at Class X of Senior High School. Journal Of Education, Teaching And Learning, 4(2). https://doi.org/10.26737/jetl.v4i2.1914.

Suhery, S., Putra, T. J., \& Jasmalinda, J. (2020). Sosialisasi Penggunaan Aplikasi Zoom Meeting Dan Google Classroom Pada Guru Di Sdn 17 Mata Air Padang Selatan. Jurnal Inovasi Penelitian, 1(3), 129-132. https://doi.org/10.47492/jip.v1i3.90.

Suriyani Djamdjuri, D., \& Kamilah, A. (2020). Whatsapp Media in Online Learning During Covid-19 Pandemic. English Journal, 14(2), 69. https://doi.org/10.32832/english.v14i2.3792.

Susilowati, E. (2020). Bagaimana Pembelajaran Daring di Tengah Wabah Covid 19 melalui Grup WhatsApp? Jurnal Pendidikan Matematika Raflesia, 05(03), 1-25. https://doi.org/10.33449/jpmr.v5i3.12896.

Tathahira, \& Sriayu. (2020). Indonesian Journal of Curriculum and Educational Technology Studies The Implementation of Online Learning During Covid-19 Pandemic: English Teachers' Perceptions at Senior High Schools in South Aceh. Ijcets, 8(2), 113-122.

Wardani, Anita, \& Ayriza, Y. (2020). Analisis Kendala Orangtua dalam Mendampingi Anak Belajar di Rumah Pada Masa Pandemi Covid-19. Jurnal Pendidikan Anak Usia Dini, 5(1). https://doi.org/10.31004/obsesi.v5i1.705.

Wardany, K., Anjarwati, S., \& Qulubi, M. H. (2021). Implementation of Online Learning Model in Class X of Senior High School during COVID-19. International Journal of Education \& Curriculum Application, $4(1), 26-32$.

Widyaningrum, H. K., Hasanudin, C., Fitrianingsih, A., Novianti, D. E., Saddhono, K., \& Supratmi, N. (2020). The Use of Edmodo Apps in Flipped Classroom Learning. How is the Students' Creative Thinking Ability? Ingénierie Des Systèmes d Inf., 25(1), 69-74. https://doi.org/10.18280/isi.250109.

Windhiyana, E. (2020). Dampak Covid-19 Terhadap Kegiatan Pembelajaran Online Di Perguruan Tinggi Kristen 
Gede Didit Ogi Wirasatya ${ }^{1}$, Luh Putu Artini ${ }^{2}$, Luh Gede Eka Wahyuni ${ }^{3}$ (2021). Jurnal Pendidikan Bahasa Inggris Undiksha. Vol. 9(3) PP. $232-240$

Di Indonesia. Perspektif Ilmu Pendidikan, 34(1), 1-8. https://doi.org/10.21009/pip.341.1.

Yawson, D. E., \& Yamoah, F. A. (2020). Understanding satisfaction essentials of E-learning in higher education:
A multi-generational
cohort
perspective.
Heliyon,
$6(11)$
e05519. https://doi.org/10.1016/j.heliyon.2020.e05519.

Zhang, Y., Ghandour, A., \& Shestak, V. (2020). Using Learning Analytics to Predict Students Performance in Moodle LMS. International Journal of Emerging Technologies in Learning. https://doi.org/10.3991/ijet.v15i20.15915. 